\title{
Facile and Green Syntheses of Unsymmetrically Substituted 3-(1-Benzyl-1H-indol-3-yl)-2-(1-ethyl-1H-indole-3-carbonyl)- acrylonitrile and Study of their Antimicrobial Activities
}

\author{
G. THIRUPATHI*, M. VENKATANARAYANA, \\ P. K. DUBEY and Y. BHARATHI KUMARI
}

Department of Chemistry, Jawaharlal Nehru Technological University, Hyderabad College of Engineering, Kukatpally, Hyderabad (A.P)-500085, India thirupathigjntuh@gmail.com

Received 7 August 2012 / Accepted 4 September 2012

\begin{abstract}
Facile and green syntheses of unsymmetrically substituted-3-(1-benzyl-1H-indol-3-yl)-2-(1ethyl- $1 H$-indole-3-carbonyl)-acrylonitriles $\mathbf{5 ( a - d )}$ is being reported. $L$-tryptophan has been utilized as an efficient and eco-friendly catalyst in the solvent free condition under the grind stone method at room temperature for Knoevenagel condensation of $N$-benzyl indole-3-carboxyaldehyde (2) with the active methylene compounds, 3-cyanoacetylindole 3(a-d) at room temperature to afford substituted3-(1-benzyl-1H-indol-3-yl)-2-(1H-indole-3-carbonyl)-acrylonitrile 4(a-d) respectively. Subsequently these products were treated with DES and $\mathrm{K}_{2} \mathrm{CO}_{3}$ in the solvent free condition under the grind stone method at room temperature to afford the corresponding substituted-3-(1-benzyl-1H-indol-3-yl)-2(1-ethyl-1 $H$-indole-3-carbonyl)-acrylonitrile 5(a-d). The antibacterial and antifungal activities of 4(a-d) and 5(a-d) have been studied.
\end{abstract}

Keywords: Indole-3-carboxyaldehyde, 3-Cyanoacetylindole, Knoevenagel reaction, $L$-tryptophan, Physical grinding

\section{Introduction}

Toda introduced a method called the grindstone method ${ }^{1}$. In this method, solids are ground together using a pestle and mortar to get the products. Recently, some solvent-free reaction conditions have been developed for oxidation ${ }^{2}$, reduction ${ }^{3}$, substitution ${ }^{4}$, condensation ${ }^{5}$ and the Michael addition ${ }^{6}$. And in many cases, these reactions are more efficient and selective than those executed in the corresponding solutions.

Developing green chemical methods is one of the most important purposes of organic synthesis. Organic synthesis in the absence of solvent is a powerful tool for the generation of structurally diverse molecules, due to their special selectivity, the ease of set-up and workup, arousing great interest. Moreover, solvent-free reactions sometime are faster, taking just a few minutes rather than hours to complete because the reactants are close contact with each other. This aspect, coupled with the lower overall costs of running a reaction without solvent and no specially needed equipment, could become a decisive factor in industry. 
Carbon-carbon bond formation reaction is the most important reaction in organic synthesis $^{7-8}$. The Knoevenagel condensation is one such reaction which facilitates C-C bond formation and has been widely used in synthesis of olefins of biological significance ${ }^{9-10}$. These reactions are usually catalyzed by bases ${ }^{11-13}$ such as ammonia, ethylenediamine, guanidine, dimethylamino pyridine, piperidine or corresponding piperidine salt, Lewis acids $^{13-15}$ in organic solvents and ionic liquids ${ }^{16-18}$ have also been added to the existing list of substances that assisted Knoevenagel condensation in organic synthesis.

As environmental consciousness in chemical research and industry has increased, efficient, economic and clean procedures have received increased attention in recent years. Varies heterogeneous basic catalysts were used in Knoevenagel condensations under solvent-free conditions. More recently, a grinding method under solvent free conditions used in Knoevenagel condensation has rapidly increased. Many catalysts have been used in the synthetic procedure, for example, $\mathrm{K}_{2} \mathrm{O}-\mathrm{Al}_{2} \mathrm{O}_{3},{ }^{19} \mathrm{CaO},{ }^{20} \mathrm{ZnCl}_{2}, \mathrm{NH}_{4} \mathrm{OAC}$ and triethyl benzyl ammonium chloride (TEBA). Knoevenagel reaction under solvent-free conditions carried out by microwave irradiation ${ }^{21-24}$ and by grinding s-28 $^{25}$ has rapidly increased.But microwave irradiation processis difficult to apply in the industrial process until now and the grinding reaction is only suitable to some active solid reactants.

\section{Experimental}

Melting points were measured in open capillary tubes and are uncorrected. TLC was done on plates coated with silica gel-G and spotting was done using iodine or UV lamp. IR spectra were recorded using FT-IR in $\mathrm{KBr}$ phase. ${ }^{1} \mathrm{H}$ NMR spectra were recorded on a Gemini-200 and AV-400 instruments operating at 200 and $400 \mathrm{MHz}$ respectively.

\section{General procedure for the preparation of $\mathbf{4 ( a - d )}$}

A mixture of 2 (10 mmol), 3 (10 mmol) and $L$-tryptophan (2 mmol) were grinded under solvent free condition at room temperature for a specified period of time (Table 1). After completion of reaction (as shown by TLC checking), the mixture was poured into ice-cold water $(50 \mathrm{~mL})$. The separated solid was filtered, washed with water $(100 \mathrm{~mL})$ and dried to obtain crude 4. The latter were then recrystallised from suitable solvent to afford pure 4(a-d).

Table 1. Synthesis of novel Knoevenagel products by using $L$-tryptophan as ecofriendly catalyst in the solvent free condition under the grind stone method ${ }^{\mathrm{a}, \mathrm{b}}$

\begin{tabular}{|c|c|c|c|c|c|c|}
\hline S.No & \multicolumn{2}{|c|}{ Reactants } & Product & 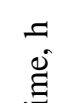 & 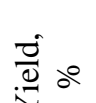 & M.P, ${ }^{\circ} \mathrm{C}$ \\
\hline 1 & $2\left(\mathrm{R}^{2}=\mathrm{Ph}-\mathrm{CH}_{2}\right)$ & За $\left(\mathrm{R}=\mathrm{H}, \mathrm{R}^{1}=\mathrm{H}\right)$ & $\begin{array}{c}4 \mathrm{a}\left(\mathrm{R}=\mathrm{H}, \mathrm{R}^{1}=\mathrm{H},\right. \\
\left.\mathrm{R}^{2}=\mathrm{Ph}-\mathrm{CH}_{2}\right)\end{array}$ & 1 & 93 & 176-178 \\
\hline 2 & $2\left(\mathrm{R}^{2}=\mathrm{Ph}-\mathrm{CH}_{2}\right)$ & $3 \mathrm{~b}\left(\mathrm{R}=\mathrm{H}, \mathrm{R}^{1}=\mathrm{OMe}\right)$ & $\begin{array}{c}4 \mathrm{~b}\left(\mathrm{R}=\mathrm{H}, \mathrm{R}^{1}=\mathrm{OMe}\right. \\
\left.\mathrm{R}^{2}=\mathrm{Ph}^{-} \mathrm{CH}_{2}\right)\end{array}$ & 1 & 92 & 258-259 \\
\hline 3 & $2\left(\mathrm{R}^{2}=\mathrm{Ph}-\mathrm{CH}_{2}\right)$ & 3c $\left(\mathrm{R}=\mathrm{H}, \mathrm{R}^{1}=\mathrm{Br}\right)$ & $\begin{aligned} 4 \mathrm{c}(\mathrm{R} & =\mathrm{H}, \mathrm{R}^{1}=\mathrm{Br} \\
\mathrm{R}^{2} & \left.=\mathrm{Ph}-\mathrm{CH}_{2}\right)\end{aligned}$ & 1 & 94 & $277-278$ \\
\hline 4 & $2\left(\mathrm{R}^{2}=\mathrm{Ph}-\mathrm{CH}_{2}\right)$ & $3 \mathrm{~d}\left(\mathrm{R}=\mathrm{H}, \mathrm{R}^{1}=\mathrm{NO}_{2}\right)$ & $\begin{array}{c}4 \mathrm{~d}\left(\mathrm{R}=\mathrm{H}, \mathrm{R}^{1}=\mathrm{NO}_{2}\right. \\
\left.\mathrm{R}^{2}=\mathrm{Ph}-\mathrm{CH}_{2}\right)\end{array}$ & 1.1 & 95 & $164-167$ \\
\hline 5 & $\begin{array}{c}4 \mathrm{a}\left(\mathrm{R}, \mathrm{R}^{1}=\mathrm{H},\right. \\
\left.\mathrm{R}^{2}=\mathrm{Ph}-\mathrm{CH}_{2}\right)\end{array}$ & DES & $\begin{array}{c}5 \mathrm{a}\left(\mathrm{R}=\mathrm{C}_{2} \mathrm{H}_{5}, \mathrm{R}^{1}=\mathrm{H},\right. \\
\left.\mathrm{R}^{2}=\mathrm{Ph}-\mathrm{CH}_{2}\right)\end{array}$ & 1 & 88 & $245-246$ \\
\hline
\end{tabular}




\begin{tabular}{|c|c|c|c|c|c|c|}
\hline 6 & $\begin{array}{c}4 \mathrm{~b}(\mathrm{R}=\mathrm{H}, \\
\mathrm{R}^{1}=\mathrm{OMe} \\
\left.\mathrm{R}^{2}=\mathrm{Ph}-\mathrm{CH}_{2}\right)\end{array}$ & DES & $\begin{array}{c}5 \mathrm{~b}\left(\mathrm{R}=\mathrm{C}_{2} \mathrm{H}_{5}, \mathrm{R}^{1}=\mathrm{OMe},\right. \\
\left.\mathrm{R}^{2}=\mathrm{Ph}-\mathrm{CH}_{2}\right)\end{array}$ & 1 & 87 & $228-229$ \\
\hline 7 & $\begin{array}{c}4 \mathrm{c}(\mathrm{R}=\mathrm{H}, \\
\mathrm{R}^{1}=\mathrm{Br} \\
\left.\mathrm{R}^{2}=\mathrm{Ph}-\mathrm{CH}_{2}\right)\end{array}$ & DES & $\begin{array}{c}5 c\left(\mathrm{R}=\mathrm{C}_{2} \mathrm{H}_{5}, \mathrm{R}^{1}=\mathrm{Br}\right. \\
\left.\mathrm{R}^{2}=\mathrm{Ph}-\mathrm{CH}_{2}\right)\end{array}$ & 1 & 89 & 281-282 \\
\hline 8 & $\begin{array}{c}4 \mathrm{~d}(\mathrm{R}=\mathrm{H}, \\
\mathrm{R}^{1}=\mathrm{NO}_{2} \\
\left.\mathrm{R}^{2}=\mathrm{Ph}-\mathrm{CH}_{2}\right)\end{array}$ & DES & $\begin{array}{c}5 \mathrm{~d}\left(\mathrm{R}=\mathrm{C}_{2} \mathrm{H}_{5}, \mathrm{R}^{1}=\mathrm{NO}_{2},\right. \\
\left.\mathrm{R}^{2}=\mathrm{Ph}-\mathrm{CH}_{2}\right)\end{array}$ & 1 & 90 & 284-286 \\
\hline
\end{tabular}

$a=$ Reaction Conditions for 4(a-d): Indole-3-carboxyaldehyde, 3-cyanoacetylindole, L- tryptophan and room temperature. $b=$ Reaction Conditions for $5(a-d): K_{2} \mathrm{CO}_{3}$, DES. Physical grinding

\section{Characterization of $\mathbf{4 a}$}

Yellow solid; Yield: 3.8 g (94.76\%); m.p. $176-178{ }^{\circ} \mathrm{C}$; IR (KBr): $3242 \mathrm{~cm}^{-1}$ (due to $-\mathrm{NH}$ ), $2212 \mathrm{~cm}^{-1}$ (due to $-\mathrm{CN}$ ) and $1621 \mathrm{~cm}^{-1}$ (due to $-\mathrm{CO}$ ); ${ }^{1} \mathrm{H}$ NMR spectrum (DMSO/d6/TMS): $\delta$ 5.61-5.62 (s, $\left.2 \mathrm{H},-\mathrm{N}_{-} \mathrm{CH}_{2}\right), 7.22-8.26(\mathrm{~m}, 13 \mathrm{H}$, aryl protons of the two indole rings and aryl protons of the benzyl rings), $\delta 8.50-8.62$ ( $\mathrm{m}, 2 \mathrm{H}, \alpha$-protons of the two indole rings), $\delta 8.74$ (vinylic proton of the indole ring), $\delta 12.18$ (br s, $1 \mathrm{H}, \mathrm{D}_{2} \mathrm{O}$ exchangeable, $-\mathrm{NH}$ proton of the indole ring); Its ${ }^{13} \mathrm{C}$ NMR spectrum (DMSO/d6/TMS): $\delta$ 61.92, 110.1, 112.1, 113.9, 115.1, 118.5, 121.7, 121.56, 121.6, 121.99,122.1, 122.3, 123.3, 123.1,123.255,126.417, 126.5, 127.074,127.288, 127.7, 131.9, 134.4, 136.3, 136.7, 145.3, 183.7; MS m/z: 402 (M+1).

\section{Characterization of $4 \boldsymbol{b}$}

Yellow solid; Yield: 3.95 g (91.64\%); m.p: 258-259 ${ }^{\circ} \mathrm{C}$; IR(KBr): $3231 \mathrm{~cm}^{-1}$ (medium, $-\mathrm{NH}$ stretching), $2208 \mathrm{~cm}^{-1}$ (sharp, -CN stretching) and $1624 \mathrm{~cm}^{-1}$ (very strong, carbonyl -CO); ${ }^{1} \mathrm{H}-\mathrm{NMR}$ (DMSO/ d6/TMS): $\delta$ 3.23-3.26 (s, 3H, $-\mathrm{OCH}_{3}$ ), 5.61-5.62 (s, $2 \mathrm{H},-\mathrm{N}_{-} \mathrm{CH}_{2}$ ), 7.22$8.26(\mathrm{~m}, 12 \mathrm{H}$, aryl protons of the two indole rings and aryl protons of the benzyl rings), $\delta$ $8.50-8.62$ (m, $2 \mathrm{H}, \alpha$-protons of the two indole rings), $\delta 8.74$ (vinylic proton of the indole ring), $\delta 12.18$ (br s, $1 \mathrm{H}, \mathrm{D}_{2} \mathrm{O}$ exchangeable, $-\mathrm{NH}$ proton of the indole ring); Its ${ }^{13} \mathrm{C}$. NMR spectrum (DMSO/d6/TMS): $\delta$, 53.1, 61.92, 110.1, 112.1, 113.9, 115.1, 118.5, 121.7, 121.56, 121.6,121.99,122.1, 122.3, 123.3, 123.1,123.255,126.417, 126.5, 127.074,127.288, 127.7, 131.9, 134.4, 136.3, 136.7, 145.3, 183.7; MS $m / z=432(M+1)$.

\section{Characterization of $4 c$}

Yellow solid; Yield: 4.46 g (92.91\%); m.p. $277-278{ }^{\circ} \mathrm{C}$; IR (KBr): $3215 \mathrm{~cm}^{-1}$ (broad, -NH stretching), $2211 \mathrm{~cm}^{-1}$ (sharp, -CN stretching) and $1615 \mathrm{~cm}^{-1}$ (very strong, highly conjugated carbonyl -CO); ${ }^{1} \mathrm{H}-\mathrm{NMR}$ (DMSO/ d6/TMS): $\delta$ 5.61-5.62 (s, $2 \mathrm{H},-\mathrm{N}-\mathrm{CH}_{2}$ ), $7.22-8.26$ $(\mathrm{m}, 12 \mathrm{H}$, aryl protons of the two indole rings and aryl protons of the benzyl rings), $\delta 8.50$ 8.62 ( $\mathrm{m}, 2 \mathrm{H}, \alpha$-protons of the two indole rings), $\delta 8.74$ (vinylic proton of the indole ring), $\delta 12.18$ (br s, $1 \mathrm{H}, \mathrm{D}_{2} \mathrm{O}$ exchangeable, $-\mathrm{NH}$ proton of the indole ring); Its ${ }^{13} \mathrm{C}$ NMR spectrum (DMSO/d6/TMS): $\delta$ 61.92, 110.1, 112.1, 113.9, 115.1, 118.5, 121.7, 121.56, 121.6, 121.99,122.1, 122.3, 123.3, 123.1,123.255,126.417, 126.5, 127.074,127.288, 127.7, 131.9, 134.4, 136.3, 136.7, 145.3, 183.7; MS $m / z=481(\mathrm{M}+1)$.

\section{Characterization of $4 d$}

Yellow solid; Yield: 4.19 g (93.94\%); m.p. 164-167 ${ }^{\circ} \mathrm{C}$; IR (KBr): $3199 \mathrm{~cm}^{-1}$ (very broad, -NH stretching), $2211 \mathrm{~cm}^{-1}$ (sharp, -CN stretching) and $1621 \mathrm{~cm}^{-1}$ (very strong, highly conjugated carbonyl -CO); ${ }^{1} \mathrm{H}$ NMR (DMSO/ d6/TMS): $\delta$ 5.61-5.62 (s, 2H, -N- $\mathrm{CH}_{2}$ ), 7.22-8.26 
( $\mathrm{m}, 12 \mathrm{H}$, aryl protons of the two indole rings and aryl protons of the benzyl rings), $\delta 8.50$ $8.62(\mathrm{~m}, 2 \mathrm{H}, \alpha$-protons of the two indole rings), $\delta 8.74$ (vinylic proton of the indole ring), $\delta$ 12.18 (br s, $1 \mathrm{H}, \mathrm{D}_{2} \mathrm{O}$ exchangeable, $-\mathrm{NH}$ proton of the indole ring); Its ${ }^{13} \mathrm{C}$ NMR spectrum (DMSO/d6/TMS): $\delta$ 61.92, 110.1, 112.1, 113.9, 115.1, 118.5, 121.7, 121.56, 121.6, 121.99,122.1, 122.3, 123.3, 123.1,123.255,126.417, 126.5, 127.074,127.288, 127.7, 131.9, 134.4, 136.3, 136.7, 145.3, 183.7. MS $m / z=447(\mathrm{M}+1)$.

\section{General procedure for the preparation of $5(\boldsymbol{a}-\mathbf{d})$ from $4(\boldsymbol{a}-\mathbf{d})$}

A mixture of 4 (10 mmole), diethyl sulphate (DES) (10 mmole), $\mathrm{K}_{2} \mathrm{CO}_{3}$ (20 mmole) were grinded under solvent free condition at room temperature for $15 \mathrm{~min}$. At the end of this period, the mixture was poured into ice-cold water. The separated solid was filtered, washed with water and dried to obtain crude product. The latter were then recrystallized from suitable solvent to afford pure $\mathbf{5 .}$

\section{Characterization of $5 a$}

Yellow solid; Yield: 3.85 g (89.74\%); m.p. $245-246{ }^{\circ} \mathrm{C}$; IR(KBr): $2201 \mathrm{~cm}^{-1}$ (medium, due to -CN stretching), $1621 \mathrm{~cm}^{-1}$ (strong, due to -CO stretching); ${ }^{1} \mathrm{H}-\mathrm{NMR}$ spectrum (DMSO/d6/TMS): $\delta$ 1.50-1.52 (s, 3H, N-CH $\mathrm{CH}_{3}$ indole ring), 4.49-4.50 (s, 2H, N-CH indole ring),7.22-8.26 (m, $12 \mathrm{H}$, aryl protons of the two indole rings and aryl protons of the benzyl rings), $\delta 8.50-8.62$ ( $\mathrm{m}, 2 \mathrm{H}, \alpha$-protons of the two indole rings), $\delta 8.74$ (vinylic proton of the indole ring), $\delta 12.18$ (br s, $1 \mathrm{H}, \mathrm{D}_{2} \mathrm{O}$ exchangeable, $-\mathrm{NH}$ proton of the indole ring); ${ }^{13} \mathrm{C}$ NMR spectrum (DMSO/d6/TMS): $\delta$ 13.8,48.9, 34.8, 110.0, 111.2, 113.1, 114.1, 118.5, 121.7, 121.4, 122.8, 123.0, 123.3, 123.8, 126.5, 127.1, 131.6, 134.2, 136.1, 136.5, 145.2, 182.1 MS m/z $=430(\mathrm{M}+1)$.

\section{Characterization of $\mathbf{5 b}$}

Yellow solid; Yield: 3.99 g (86.92\%); m.p. 228-229 ${ }^{\circ} \mathrm{C}$; IR (KBr): $2167 \mathrm{~cm}^{-1}$ (sharp, -CN stretching) and $1616 \mathrm{~cm}^{-1}$ (very strong, highly conjugated carbonyl $-\mathrm{C}=\mathrm{O}$ ); ${ }^{1} \mathrm{H}$ NMR (DMSO/ d6/TMS): $\delta 3.24-3.25$ (s, 3H, $-\mathrm{O}_{-} \mathrm{CH}_{3}$ ), 1.50-1.52 (s, 3H, $\mathrm{N}-\mathrm{CH}_{3}$ of indole ring), 4.49-4.50 (s, $2 \mathrm{H}, \mathrm{N}-\mathrm{CH}_{2}$ of indole ring),7.22-8.26 (m, 12H, aryl protons of the two indole rings and aryl protons of the benzyl rings), $\delta 8.50-8.62(\mathrm{~m}, 2 \mathrm{H}, \alpha$-protons of the two indole rings), $\delta 8.74$ (vinylic proton of the indole ring), $\delta 12.18$ (br s, $1 \mathrm{H}, \mathrm{D}_{2} \mathrm{O}$ exchangeable, $-\mathrm{NH}$ proton of the indole ring); ${ }^{13} \mathrm{C}$ NMR spectrum (DMSO/d6/TMS): $\delta$ 13.8,48.9, 34.8, 61.92, $110.1,112.1,113.9,115.1,118.5,121.7,121.56,121.6$,121.99,122.1, 122.3,123.3, 123.1,123.255,126.417, 126.5, 127.074,127.288, 127.7, 131.9, 134.4, 136.3, 136.7, 145.3, 183.7; $\mathrm{MS} \mathrm{m} / \mathrm{z}=460(\mathrm{M}+1)$.

\section{Characterization of $5 c$}

Yellow solid; Yield: 4.47 g (87.99\%); m.p. 281-282 ${ }^{\circ} \mathrm{C}$; IR (KBr): $2212 \mathrm{~cm}^{-1}$ (sharp, -CN stretching) and $1616 \mathrm{~cm}^{-1}$ (very strong, highly conjugated carbonyl $-\mathrm{C}=\mathrm{O}$ ); ${ }^{1} \mathrm{H}$ NMR (DMSO/ d6/TMS): $\delta 1.50-1.52$ (s, 3H, N-CH ${ }_{3}$ of indole ring), 4.49-4.50 (s, 2H, N-CH $\mathrm{CH}_{2}$ indole ring),7.22-8.26 (m, $12 \mathrm{H}$, aryl protons of the two indole rings and aryl protons of the benzyl rings), $\delta 8.50-8.62(\mathrm{~m}, 2 \mathrm{H}, \alpha$-protons of the two indole rings), $\delta 8.74$ (vinylic proton of the indole ring), $\delta 12.18$ (br s, $1 \mathrm{H}, \mathrm{D}_{2} \mathrm{O}$ exchangeable, $-\mathrm{NH}$ proton of the indole ring); Its ${ }^{13} \mathrm{C}-\mathrm{NMR}$ spectrum (DMSO/d6/TMS): $\delta$ 13.8,48.9, 34.8, 61.92, 110.1, 112.1, 113.9, 115.1, 118.5, 121.7, 121.56, 121.6 ,121.99,122.1, 122.3, 123.3, 123.1,123.255, $126.417,126.5,127.074,127.288,127.7,131.9,134.4,136.3,136.7,145.3,183.7$; MS $\mathrm{m} / \mathrm{z}=509(\mathrm{M}+1)$. 


\section{Characterization of 5d}

Yellow solid; Yield: 4.26 g (89.87\%); m.p. 284-286 ${ }^{\circ}$; IR (KBr): $2222 \mathrm{~cm}^{-1}$ (sharp, -CN stretching) and $1618 \mathrm{~cm}^{-1}$ (very strong, highly conjugated carbonyl $-\mathrm{C}=\mathrm{O}$ ); ${ }^{1} \mathrm{H} \mathrm{NMR}$ (DMSO/d6/TMS): $\delta$ 1.50-1.52 (s, 3H, N-CH ${ }_{3}$ of indole ring), 4.49-4.50 (s, 2H, $\mathrm{N}-\mathrm{CH}_{2}$ of indole ring),7.22-8.26 (m, 12H, aryl protons of the two indole rings and aryl protons of the benzyl rings), $\delta 8.50-8.62$ (m, $2 \mathrm{H}, \alpha$-protons of the two indole rings), $\delta 8.74$ (vinylic proton of the indole ring), $\delta 12.18$ (br s, $1 \mathrm{H}, \mathrm{D}_{2} \mathrm{O}$ exchangeable, $-\mathrm{NH}$ proton of the indole ring); Its ${ }^{13} \mathrm{C}$ NMR spectrum (DMSO/d6/TMS): $\delta 13.8,48.9,34.8,61.92,110.1,112.1,113.9,115.1,118.5$, 121.7, 121.56, 121.6, 121.99,122.1, 122.3, 123.3, 123.1,123.255,126.417, 126.5, 127.074, 127.288, 127.7, 131.9, 134.4, 136.3, 136.7, 145.3, 183.7; MS m/z = 475 (M+1).

\section{Antimicrobial activity}

\section{Antibacterial activity}

All the compounds substituted-3-(1-benzyl-1H-indol-3-yl)-2-(1H-indole-3-carbonyl)-

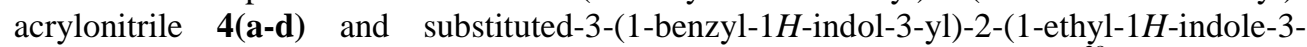
carbonyl)-acrylonitrile 5(a-d) were screened for their antibacterial activities ${ }^{38}$ against grampositive bacteria such as Bacillus subtilis, Staphylococcus aureus (ATCC6538) and also against gram-negative bacteria such as Klebsiella pneumonia, Escherichia coli (ATCC8739) bacterial strains $^{39}$ at concentrations of 50, 100, 200, 300 and $500 \mu \mathrm{g} / \mathrm{mL}$. Streptomycin was used as a reference standard. Petri plates and necessary glassware were sterilized in hot air oven at $190{ }^{\circ} \mathrm{C}$ for $45 \mathrm{~min}$. The muelier hinton agar and saline $(0.82 \% \mathrm{Nacl})$ media were sterilized in autoclave $\left(121{ }^{\circ} \mathrm{C}, 15 \mathrm{psi}, 20 \mathrm{~min}\right)$. Inoculum was prepared in sterile saline $(0.82 \% \mathrm{Nacl})$ and the optical density of all pathogens was adjusted to 0.10 at $625 \mathrm{~nm}$ on a chemito spectra scan UV 2600 spectrophotometer that is equivalent to 0.5Mc Farland standards ${ }^{40}$. The muelier hinton agar plates were prepared by the pour plate method. The activity of the compounds was tested by agar disc diffusion method. All the bacterial cells were cultured in muelier hinton agar plates and the compounds to be tested were dissolved in $N, N$-dimethyl-formamide(DMF) and were soaked in agar disc and the Petri plates incubated at $37^{\circ} \mathrm{C}$ for $24 \mathrm{~h}$. The diameter (mm) of the zone of inhibition around each agar disc was measured and results were recorded in Table 4. 4(a-d) and 5(a-d) compounds tested were found to have excellent anti-bacterial activity against klebsiella pneumoniae and Escherichia coli. However, they were found to have moderate activity against Staphylococcus aureus and Bacillus subtilis.

Table 4. Antibacterial activity of $\mathbf{4 ( a - d )}$ and 5(a-d) against Klebsiella pneumonia, Escherichia coli, Staphylococcus aureus and Bacillus subtilis

\begin{tabular}{|c|c|c|c|c|c|c|c|}
\hline \multirow[b]{2}{*}{ S.No } & \multirow{2}{*}{$\begin{array}{l}\text { Compound } \\
\text { No. }\end{array}$} & \multirow[b]{2}{*}{ Types of bacteria } & \multicolumn{5}{|c|}{ Inhibition zone in mm for concentration of } \\
\hline & & & $\begin{array}{c}50 \\
\mu \mathrm{g} / \mathrm{mL}\end{array}$ & $\begin{array}{c}100 \\
\mu \mathrm{g} / \mathrm{mL}\end{array}$ & $\begin{array}{c}200 \\
\mu \mathrm{g} / \mathrm{mL}\end{array}$ & $\begin{array}{c}300 \\
\mu \mathrm{g} / \mathrm{mL}\end{array}$ & $\begin{array}{c}500 \\
\mu \mathrm{g} / \mathrm{mL}\end{array}$ \\
\hline \multirow[t]{4}{*}{1} & $4 a$ & $\begin{array}{l}\text { Klebsiella } \\
\text { pneumonia }\end{array}$ & 9 & 14 & 18 & 23 & 31 \\
\hline & & Escherichia coli & 8 & 13 & 16 & 20 & 30 \\
\hline & & $\begin{array}{l}\text { Staphylococcus } \\
\text { aureus }\end{array}$ & 6 & 10 & 14 & 18 & 25 \\
\hline & & Bacillus subtilis & 4 & 9 & 12 & 15 & 23 \\
\hline
\end{tabular}




\begin{tabular}{|c|c|c|c|c|c|c|c|}
\hline \multirow[t]{4}{*}{2} & $4 \mathbf{b}$ & Klebsiella pneumonia & 9 & 14 & 18 & 23 & 32 \\
\hline & & Escherichia coli & 8 & 13 & 15 & 20 & 31 \\
\hline & & Staphylococcus aureus & 6 & 10 & 13 & 16 & 26 \\
\hline & & Bacillus subtilis & 4 & 9 & 11 & 14 & 22 \\
\hline \multirow[t]{4}{*}{3} & 4c & Klebsiella pneumonia & 9 & 14 & 18 & 23 & 32 \\
\hline & & Escherichia coli & 8.4 & 13.5 & 14 & 21 & 30 \\
\hline & & Staphylococcus aureus & 6 & 10 & 13 & 17 & 25 \\
\hline & & Bacillus subtilis & 5 & 9.5 & 11 & 15 & 23 \\
\hline \multirow[t]{4}{*}{4} & 4d & Klebsiella pneumonia & 9 & 14 & 18 & 23 & 32 \\
\hline & & Escherichia coli & 8 & 13 & 15 & 20 & 31 \\
\hline & & Staphylococcus aureus & 6 & 10 & 13 & 16 & 26 \\
\hline & & Bacillus subtilis & 4 & 9 & 11 & 14 & 22 \\
\hline \multirow[t]{4}{*}{5} & $5 a$ & Klebsiella pneumonia & 9 & 14 & 18 & 23 & 31 \\
\hline & & Escherichia coli & 8 & 13 & 16 & 20 & 30 \\
\hline & & Staphylococcus aureus & 6 & 10 & 14 & 18 & 25 \\
\hline & & Bacillus subtilis & 4 & 9 & 12 & 15 & 23 \\
\hline \multirow[t]{4}{*}{6} & $5 b$ & Klebsiella pneumonia & 9 & 14 & 18 & 23 & 32 \\
\hline & & Escherichia coli & 8 & 13 & 15 & 20 & 31 \\
\hline & & Staphylococcus aureus & 6 & 10 & 13 & 16 & 26 \\
\hline & & Bacillus subtilis & 4 & 9 & 11 & 14 & 22 \\
\hline \multirow[t]{4}{*}{7} & $5 c$ & Klebsiella pneumonia & 9 & 4 & 18 & 23 & 32 \\
\hline & & Escherichia coli & 8.4 & 13.5 & 14 & 21 & 30 \\
\hline & & Staphylococcus aureus & 6 & 10 & 13 & 17 & 25 \\
\hline & & Bacillus subtilis & 5 & 9.5 & 11 & 15 & 23 \\
\hline \multirow[t]{4}{*}{8} & 5d & Klebsiella pneumonia & 9 & 14 & 18 & 23 & 31 \\
\hline & & Escherichia coli & 8 & 13 & 16 & 20 & 30 \\
\hline & & Staphylococcus aureus & 6 & 10 & 14 & 18 & 25 \\
\hline & & Bacillus subtilis & 4 & 9 & 12 & 15 & 23 \\
\hline \multirow[t]{4}{*}{9} & Strepto & Klebsiella pneumonia & Klebsiella pneumonia & 14 & 18 & 23 & 32 \\
\hline & mycin & Escherichia coli & Escherichia coli & 13 & 15 & 20 & 31 \\
\hline & & Staphylococcus aureus & Staphylococcus aureus & 10 & 13 & 16 & 26 \\
\hline & & Bacillus subtilis & Bacillus subtilis & 9 & 11 & 14 & 22 \\
\hline
\end{tabular}

Antifungal activity

All the compounds $\mathbf{4 ( a - d )}$ and 5(a-d) synthesized compound were screened for antifungal activity against Rhizoctonia solani, Fusarium oxysporum, Aspergillus Niger and Aspergillus flavus at concentrations of 50,100, 200, 300 and $500 \mu \mathrm{g} / \mathrm{mL}$. Mycostatin was used as a reference standard. Potato dextrose agar (PDA) was used as basal medium for test fungi. Glass petridishes used were sterilized. Sterilized melted PDA medium $\left(\sim 45^{\circ} \mathrm{C}\right)$ was poured at the rate of $15 \mathrm{~mL}$ into each petridish $(90 \mathrm{~mm})$. After solidification of the medium, small portions of the mycelium of each fungus were spread carefully over the centre of each PDA plate with the help of sterilized needles. Thus, each fungus was transferred to a number of PDA plates, which were then incubated at $(25 \pm 2){ }^{\circ} \mathrm{C}$ and ready for use after five days of incubation. Prepared discs of samples were placed gently on solidified agar plates, freshly seeded with the test organisms with sterile forceps. A control disc was also placed on the test plates to compare the effect of the test samples and to nullify the effect of solvent respectively. The plates were then kept in a refrigerator at $4{ }^{\circ} \mathrm{C}$ for $24 \mathrm{~h}$ so that the materials had sufficient time to diffuse over a considerable 
area of the plates. After this, the plates were incubated at $37^{\circ} \mathrm{C}$ for $72 \mathrm{~h} . \mathrm{N}, \mathrm{N}$-dimethylformamide (DMF) was used as solvent to prepare desired solutions of the compounds and also to maintain proper control. The diameter $(\mathrm{mm})$ of the zone of inhibition around each agar disc was measured and results were recorded in Table 5. 4(a-d) and 5(a-d) compounds tested were found to have very good antifungal activity against Rhizoctonia solani and Fusarium oxysporum. However, they were found to good activity against Aspergillus niger and Aspergillus flavus.

Table 5. Antifungal activity of $\mathbf{4 ( a - d )}$ and 5(a-d) against Rhizoctonia solani, Fusarium oxysporum, Aspergillus niger and Aspergillus flavus

\begin{tabular}{|c|c|c|c|c|c|c|c|}
\hline \multirow[b]{2}{*}{ S.No } & \multirow{2}{*}{$\begin{array}{c}\text { Compound } \\
\text { No. }\end{array}$} & \multirow[b]{2}{*}{ Types of fungus } & \multicolumn{5}{|c|}{ Zone of inhibition in mm for concentration of } \\
\hline & & & $\begin{array}{c}50 \\
\mu \mathrm{g} / \mathrm{mL}\end{array}$ & $\begin{array}{c}100 \\
\mu \mathrm{g} / \mathrm{mL}\end{array}$ & $\begin{array}{c}200 \\
\mu \mathrm{g} / \mathrm{mL}\end{array}$ & $\begin{array}{c}300 \\
\mu \mathrm{g} / \mathrm{mL}\end{array}$ & $\begin{array}{c}500 \\
\mu \mathrm{g} / \mathrm{mL}\end{array}$ \\
\hline \multirow[t]{4}{*}{1} & \multirow[t]{4}{*}{ 4a } & Rhizoctonia solani & 9 & 14 & 18 & 23 & 31 \\
\hline & & Fusarium oxysporum & 9 & 13.8 & 17 & 22.6 & 30 \\
\hline & & Aspergillus niger & 6 & 10 & 14 & 18 & 25 \\
\hline & & Aspergillus flavus & 6.5 & 11 & 13.6 & 18.3 & 25.2 \\
\hline \multirow[t]{4}{*}{2} & \multirow[t]{4}{*}{$4 \mathbf{b}$} & Rhizoctonia solani & 8 & 13 & 15 & 20 & 31 \\
\hline & & Fusarium oxysporum & 8 & 13 & 14 & 19 & 30 \\
\hline & & Aspergillus niger & 4 & 9 & 11 & 14 & 22 \\
\hline & & Aspergillus flavus & 4.3 & 8.9 & 11.1 & 13.9 & 22.1 \\
\hline \multirow[t]{4}{*}{3} & \multirow{4}{*}{$4 c$} & Rhizoctonia solani & 8.4 & 13.5 & 14 & 21 & 30 \\
\hline & & Fusarium oxysporum & 8 & 13 & 13 & 20 & 29 \\
\hline & & Aspergillus niger & 5 & 9.5 & 11 & 15 & 23 \\
\hline & & Aspergillus flavus & 5 & 9 & 10.8 & 14.8 & 23 \\
\hline \multirow[t]{4}{*}{4} & \multirow[t]{4}{*}{ 4d } & Rhizoctonia solani & 9 & 14 & 18 & 23 & 32 \\
\hline & & Fusarium oxysporum & 8 & 13 & 15 & 20 & 31 \\
\hline & & Aspergillus niger & 6 & 10 & 12 & 15 & 23 \\
\hline & & Aspergillus flavus & 4 & 9 & 11 & 14 & 22 \\
\hline \multirow[t]{4}{*}{5} & \multirow[t]{4}{*}{$5 a$} & Rhizoctonia solani & 9 & 14 & 18 & 23 & 31 \\
\hline & & Fusarium oxysporum & 8 & 13 & 16 & 20 & 30 \\
\hline & & Aspergillus niger & 6 & 10 & 14 & 18 & 25 \\
\hline & & Aspergillus flavus & 4 & 9 & 12 & 15 & 23 \\
\hline \multirow[t]{4}{*}{6} & \multirow{4}{*}{$5 \mathbf{b}$} & Rhizoctonia solani & 9 & 14 & 18 & 23 & 32 \\
\hline & & Fusarium oxysporum & 8 & 13 & 15 & 20 & 31 \\
\hline & & Aspergillus niger & 6 & 10 & 13 & 16 & 26 \\
\hline & & Aspergillus flavus & 4 & 9 & 11 & 14 & 22 \\
\hline \multirow[t]{4}{*}{7} & \multirow[t]{4}{*}{$5 c$} & Rhizoctonia solani & 9 & 14 & 18 & 23 & 32 \\
\hline & & Fusarium oxysporum & 8.4 & 13.5 & 14 & 21 & 30 \\
\hline & & Aspergillus niger & 6 & 10 & 13 & 17 & 25 \\
\hline & & Aspergillus flavus & 5 & 9.5 & 11 & 15 & 23 \\
\hline \multirow[t]{4}{*}{8} & \multirow[t]{4}{*}{ 5d } & Rhizoctonia solani & 9 & 14 & 18 & 23 & 32 \\
\hline & & Fusarium oxysporum & 8 & 13 & 15 & 20 & 31 \\
\hline & & Aspergillus niger & 6 & 10 & 13 & 16 & 26 \\
\hline & & Aspergillus flavus & 4 & 9 & 11 & 14 & 22 \\
\hline \multirow[t]{4}{*}{13} & \multirow[t]{4}{*}{ Mycostanin } & Rhizoctonia solani & 13 & 16 & 20 & 28 & 35 \\
\hline & & Fusarium oxysporum & 13 & 16 & 19 & 27 & 35 \\
\hline & & Aspergillus niger & 9.2 & 11 & 14.6 & 21 & 30 \\
\hline & & Aspergillus flavus & 9 & 11 & 14 & 20 & 29 \\
\hline
\end{tabular}




\section{Results and Discussion}

Treatment of $N$-benzyl indole-3-carboxyaldehyde (2) with 3-cyanoacetylindoles 3(a-d) in the presence of $L$-tryptophan in the solvent free condition under the grind stone method at RT for $10 \mathrm{~min}$. resulted in the formation of substituted 3-(1-benzyl-1H-indol-3-yl)-2-(1Hindole-3-carbonyl)acrylonitriles 5(a-d) in 92-95\% yields (Table 1, Scheme 1). This method is very facile and convenient for the preparation of large amount of Knoevenagel adducts with high yields in less time. $L$-tryptophan acts as a base to induce the reaction.

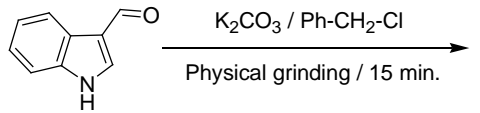

(1)

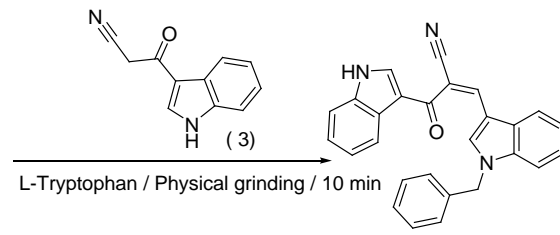

(4)
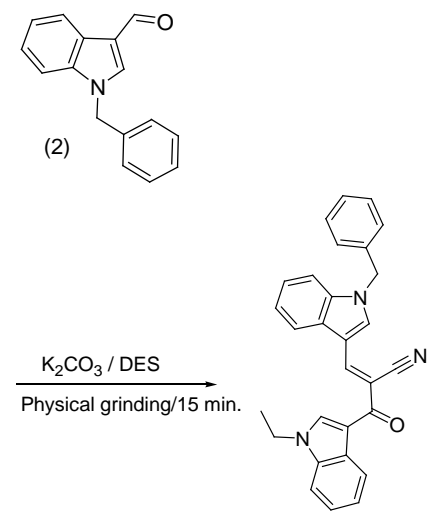

(5)

Scheme 1. Knoevenagel condensation of $N$-benzyl indole-3-carboxy aldehyde with 3 -cyanoacetylindole in presense of $L$-tryptophan under solvent free condition

In the absence of $L$-tryptophan, the reaction does not proceed the reactants in the solvent free condition under grind stone method at room temperature for $4 \mathrm{~h}$. The use of $L$-tryptophan as a catalyst helps to avoid the use of environmentally unfavourable organic solvents (DMF, C6H6, Toluene, DMSO, etc....,) as reaction medium. It is inexpensive, readily available and found to retain its activity even in the presence of water and other active functional groups such as $\mathrm{CHO},-\mathrm{CO}, \mathrm{NO} 2$ and $\mathrm{CN}$ present in the substrates. In all cases, the reaction proceeded smoothly with catalytic amount of $L$-tryptophan to give products of good purity. In the above reaction, the product has been assigned E-configuration (first and second priority groups i.e., indolyl and 3-cyanoacetylindol respectively are trans to each other) on the basis of the assumption that the groups with maximum stereo chemical bulk would be more stable in a trans configuration.

The above reactions of $N$-benzyl indole-3-carboxyaldehyde (2) with 3-cyanoacetylindoles 3(a-d) were attempted in the presence of various bases like $\mathrm{NaOH}, \mathrm{KOH}$ were too strong bases to result in more by products. $\mathrm{K}_{2} \mathrm{CO}_{3}$, ammonium acetate can not catalyze effectively this reaction under same conditions. Low yield was obtained and long reaction time is needed using piperidine and triethylamine as catalyst for condensation of $N$-benzyl aldehyde-3-carboxyaldehyde with 3-cyanoacetylindole in the solvent free condition under the grind stone method at room temperature.

From Table 1, it was shown that the condensation of 3-cyanoacetylindole with electron withdrawing group such as $-\mathrm{Br}$ and $-\mathrm{NO}_{2}$ at 5-th position of indole ring with $N$-benzyl indole -3-carboxyaldehyde can be carried out in relatively shorter time and higher yield than with electron donating group such as $-\mathrm{OCH}_{3}$ in the solvent free condition under the grind stone method at room temperature. 
A plausible mechanism for the formation of $\mathbf{4}$ from $\mathbf{2}$ and $\mathbf{3}$ in the presence of $L$-tryptophan as catalyst is shown in the Scheme 2. In the mechanism shown in Scheme 2, $L$-tryptophan, in its zwitterionic form (Ib), abstracts a proton from 3-cyanoacetylindole (3) forming the carbanion of 3-cyanoacetylindole i.e. $\left(\mathbf{3}^{\mathbf{1}}\right)$ which then attacks the protonated indole-3-carboxyaldehyde $\left(\mathbf{1}^{\mathbf{1}}\right)$ forming the corresponding intermediate $\left.\mathbf{( 1}^{\mathbf{1 1}}\right)$ that loses water to form the end product $\mathbf{4}$.which on alkylation results the title compound $\mathbf{5}$.<smiles>NC(Cc1c[nH]c2ccccc12)C(=O)O</smiles><smiles>Cc1ccccc1CC(=O)C(=O)OC([NH3+])Cc1c[nH]c2ccccc12</smiles><smiles>C=C=C=CC(=O)c1c[nH]c2ccccc12</smiles>

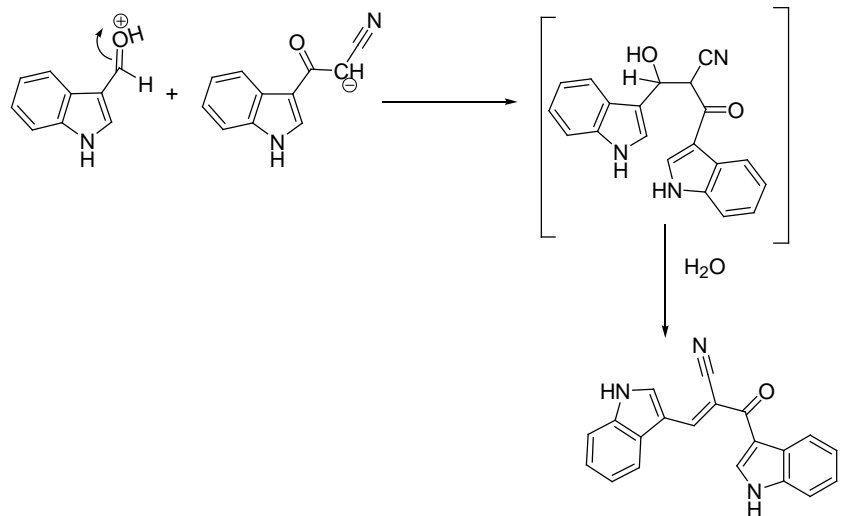

Scheme 2. Plausible mechanism for the formation of 4 from $2 \& 3$ in the presence of $L$-tryptophan under solvent free condition at room temperature

Treatment of $\mathbf{4 ( a - d )}$ each with DES independently, $\mathrm{K}_{2} \mathrm{CO}_{3}$ as base in the solvent free condition under the grind stone method at room temperature for $15 \mathrm{~min}$. resulted

unsymmetrically substituted 3-(1-benzyl- $1 H$-indol-3-yl)-2-(1-ethyl-1 $H$-indole-3-carbonyl) acrylonitriles 5(a-d) respectively in $87-90 \%$ yields (Scheme 1). Treatment of indole-3carboxyldehyde with benzyl chloride, $\mathrm{K}_{2} \mathrm{CO}_{3}$ as base in the solvent free condition under the grind stone method at room temperature for $15 \mathrm{~min}$. resulted $\mathrm{N}$-benzyl indole-3carboxyaldehyde (2). All the above reactions are summarized in Scheme 1.

It is obvious from the above results that $\mathrm{K}_{2} \mathrm{CO}_{3}$ as base in the solvent free condition under the grind stone method at room temperature for alkylation of $\mathbf{2}$ and $\mathbf{4 ( a - d )}$ resulting 5(a-d) respectively. 


\section{Conclusion}

$L$-Tryptophan has been employed as an efficient catalyst for the preparation of indolo olefinic compounds by a Knoevenagel reaction in the solvent free condition under the grind stone method at room temperature. This method is applicable to a wide range of $\mathrm{N}$ substituted indole-3-carboxyldehydes (2) and active methylene compounds. The attractive features of this procedure are the mild reaction conditions, high conversions, operational simplicity and inexpensive and ready availability of the catalyst, all of which make it a useful and attractive strategy for the preparation of olefins.

\section{Acknowledgement}

The authors are thankful to the Jawaharlal Nehru Technological University Hyderabad, India for providing financial support and to the principal of Jawaharlal Nehru Technological University Hyderabad college of Engineering, Kukatpally, Hyderabad for providing laboratory facilities.

\section{Reference}

1. Tannaka K and Toda F, Chem Rev., 2000, 100, 1025-1074.

2. Rasmussen M O, Axelsson O and Tanner D, Syn Commun., 1997, 27, 4027-4030.

3. Mehta G, Khan F A and Lakshmi K A, Tetrahedron Lett., 1992, 33, 7977-7980.

4. Smrcina M, Vyskocil S, Hanus V, Polasek M and Langer V, Chew B G M and Zax D B, J Am Chem Soc., 1996, 118, 487-489.

5. (a) Ren Z J, Cao W G and Tong W Q, Synth Commun., 2002, 32(22), 3475-3479;

(b) Geng L J, Wang S X, Li J T and Liu C H, Youji Huaxue, Chinese J Org Chem., 2002, 22(12), 1047-1049.

6. (a) Satish G B, Panneerselvam K, Zacharias D E and Desiraju G R, J Chem Soc Perkin Trans 2, 1995, 325-330; (b) Li X L, Wang Y M, Matsuura T and Meng J B, J Heterocycl Chem., 1999, 36(3), 697-701.

7. (a) Knoevenagel E, Berichte, 1898, 31, 2585-2596, (b) Jones G, The Knoevenagel condensation reaction. In Organic Reactions, Wiley: New York, 1967, 15, 204.

8. (a) Tietze L F and Beifuss U, Comprehensive Organic Synthesis; Trost B M, Fleming I and Heathcock C H, Eds., Pergamon: Oxford, 1991, 2, 341-392.

9. $\quad$ Bose D S and Narsaiah A V, J Chem Research (S), 2001, 36-38.

10. (a) Lyall R M, Zilberstien A, Gazit A, Gilon C, Levitzki A and Schlessinger J, Bio Chem., 1989, 264(24), 14503-14503-14509; (b) Shiraishi T, Owada M K, Tatsuki M, Yamashita Y and Kaunaga T, Cancer Res., 1989, 49, 2374-2378.

11. (a) Allen C F H and Spangler F W, Org Synth Coll., 1955, III, 377-379; (b) Rand L, Swisher J V and Cronin C J, J Org Chem., 1962 , 27, 3505-3507.

12. (a) Rao P S and Venkataratnam R V, Tetrahedron Lett., 1991, 32, 5821-5822;

(b) Prajpati D, Lekhok K C, Sandhu J S and Ghosh A C, J Chem Soc., Pekin Trans 1, 1996, 959

13. Rao P S and Venkataratnam R V, Tetrahedron Lett., 1991, 32(41), 5821-5822.

14. Prajapati D and Sandhu J S, J Chem Soc Perkin Trans 1, 1993, 739-740.

15. Moison H, Texier-Boullet F and Foucaud A, Tetrahedron, 1987, 43, 537-542.

16. Darvatkar N B, Deorukhar A R, Bhilare S V and Salunkhe M M, Synth Commun., 2006, 36, 3043-3051.

17. (a) Hu Y, Chen J, Le Z G and Zheng Q G, Synth Commun., 2005, 35, 739-744;

(b) Khan F A, Dash J, Satapahty R and Upahyay S K, Tetrahedron Lett., 2004, 45, 3055-3058; (c) Harjani J R, Nara S J and Salunkhe M M, Tetrahedron Lett., 2002, 43, 1127-1130. 
18. Darvatkar N B, Deorukhkar A R, Bhilare S V and Salunkhe M M, Synth Commun., 2006, 36, 3043-3051.

19. $\quad$ Wang S X, Li J T, Yang W Z, Yin Y H and Xie Z H, Synth Commun., 2004, 34, 829.

20. Lu Y Y, Ren Z J, Cao W G, Tong W Q and Gao M F, Synth Commun., 2004, 34(11), 2047-2051.

21. Balalaie S and Nemati N, Synth Commun., 2000, 30, 869.

22. Fildes D, Caignaert V, Villemin D and Jaffres P A, Green Chem., 2001, 3, 52-56.

23. Mongilaiah K and Prashanthi G, Synth Commun., 2003, 33, 2309.

24. Bogdal D, J Chem Res (s), 1998, 468.

25. Geng L J, Wang S X, Li J T and Liu C H, Chin J Org Chem., 2002, 22, 1047.

26. Tu S J, Rong L C, Gao Y, Guo S M, Lu S H and Yang X J, Chin J Org Chem., 2002, 22(5), 364.

27. Watson B T and Christiansen G E, Tetrahedron Lett., 1998, 39, 6087-6090.

28. (a) Prajapati D, Lekhok K C, Sandhu J S and Ghosh A C, J Chem Soc Perkin Trans 1, 1996, 9, 959.

29. Frankel S, Reitman S and Sonnenwirth A C, Gradwol's Clinical Laboratory Methods and Diagnosis, Textbook on a Laboratory Procedure and Their Interpretation, $7^{\text {th }}$ Edn., 1970, 2, 1406.

30. Maron D M and Ames B N, Mutation Res., 1983, 113(3-4), 173-215.

31. Kilic A, Baysallar M, Besirbellioglu B, Salih B, Sorkun K and Tanyuksel M, Ann Microbiol., 2005, 55(2), 113-117. 